\title{
Projecting With the St. Louis Model: A Progress Report
}

\author{
by KEITH M. CARLSON
}

$\mathrm{T}$ HE ST. LOUIS model was designed to project the general time path of response of certain key economic variables to monetary and fiscal actions. ${ }^{1}$ What can be said, in retrospect, about the success of the model in achieving its stated objectives?

The period from fourth quarter 1969 to second quarter 1971 is taken as the focus of discussion. Late 1969 is chosen as the starting point for the analysis because the current version of the St. Louis model was developed at that time. Mid-1971 is selected as the terminal point of reference because of the adoption of an incomes policy in mid-August. The model, as designed, is not able to capture the short-run effects of price-wage controls, nor does it allow incorporation of the effects of restructured international monetary arrangements. The model is purposely kept small to aid in the identification of the fundamental determinants of economic trends over periods as long as a year or more.

The St. Louis model is small in size and is not designed for quartertorquarter forecasting because many factors are known to influence short-run movements in economic activity. For this reason, the model's performance is examined for the six-quarter period as a whole, rather than quarter by quarter.

There are three exogenous variables in the St. Louis model - changes in the money stock and high employment Federal expenditures, considered summary measures of monetary and fiscal actions, and potential output, which reflects growth of the labor force and productivity. ${ }^{2}$ In using the model for purposes of monetary policy recommendation, alter-

TLeonall C. Andersen and Jerry L. Jordan, "Monetary and Fiscal Actions: A Test of Their Relative Importance in Economic Stabilization," this Review (November 1968), pp. 11-24, and Leonall C. Andersen and Keith M. Carlson,

"A Monetarist Model for Economic Stabilization," this Review (April 1970), pp. 7-25.

${ }^{2}$ For a discussion of the role of potential output in the $5 t$ Louis model, see Roger $W$. Spencer, "Population, Labor Force, and Potential Output: Implications for the St. Lotis Model," this Retiew (February 1971), pp. 15-23. native steady growth rates of the money stock are assumed. This procedure does not entail forecasting movements in the money stock over short periods. Instead, it presents a set of simulations using alternative steady growth rates which can aid in assessing the economic impact over several quarters of different trend growth rates of money.

\section{Background}

The economy was in the early stage of a recession in late $1969 .^{3} \mathrm{GNP}$ had risen 7.5 percent in 1969 , compared with 8.9 percent the previous year, and the rate of increase from third to fourth quarter of 1969 had slowed to 3.4 percent. Real product had declined from third to fourth quarter 1969. Despite a slowdown of growth in nominal and real terms, prices had continued to accelerate through 1969.

St. Louis model projections in early 1970 indicated there was little prospect of strong economic recovery in 1970 because of the lagged effect of monetary restraint in $1969{ }^{*}$ For example, assuming 6 percent growth in money, real output was projected to decline in the first two quarters of 1970 , pick up slightly in the second half, then advance at a 3.5 to 4 percent rate in 1971 .

The outlook for prices with a 6 percent rate of monetary growth was for a very slow decline in the rate of inflation throughout the projection period from a 4.7 percent rate of increase in fourth quarter 1969 , to a 4.3 percent rate in fourth quarter 1970 , and a 3.8 percent rate in late 1971. Unemployment was projected to rise quite rapidly in 1970 , then level off in 1971 at about 5.7 percent.

The model presented a mixed picture for interest rates. Long-term rates were projected to change

"See "Real Economic Expansion Pauses," this Review (February 1970 ), pp. 277

"See Andersen and Carlson, "A Monetarist Model," p. 19. 


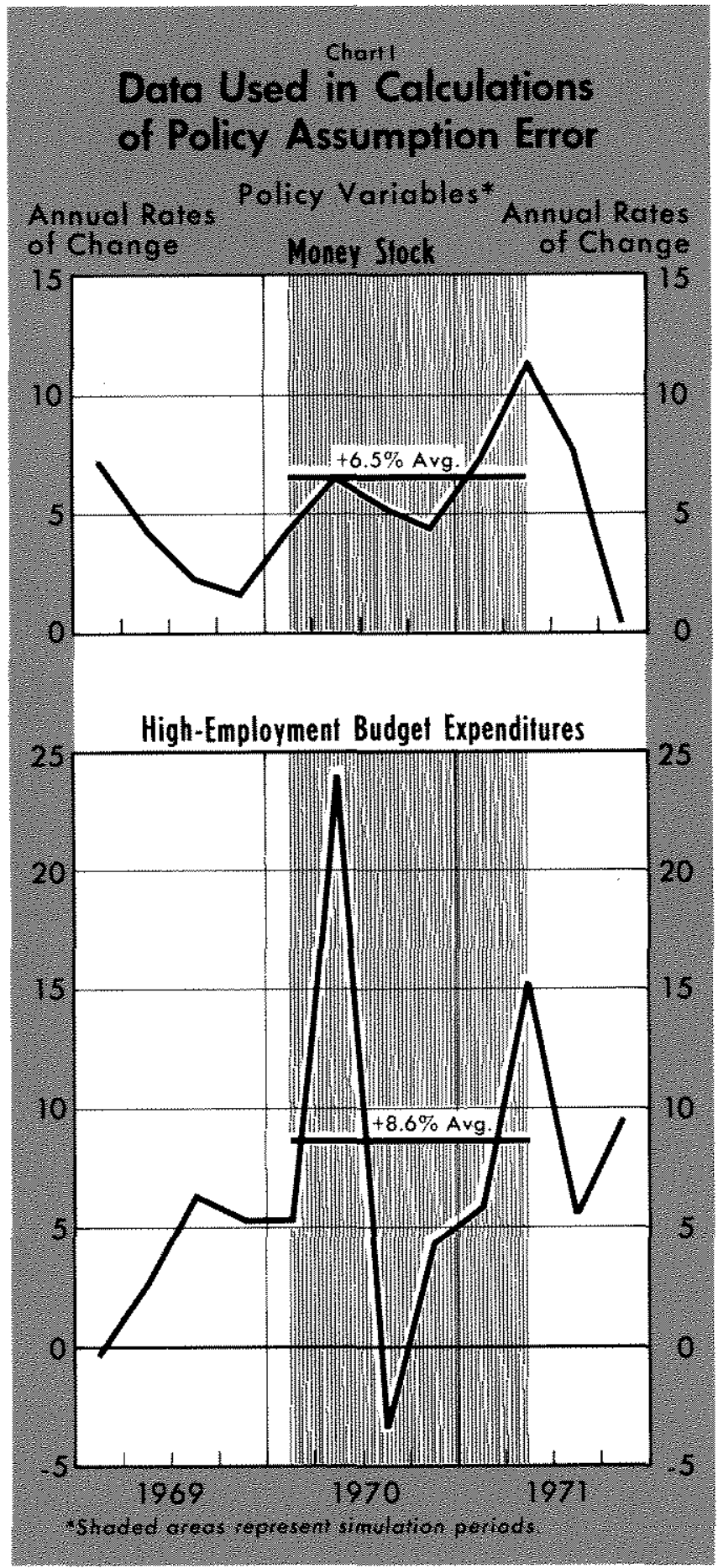

little for the period through 1971, while shortterm rates were projected to decline sharply in 1970 , to about 6.3 percent, then drop further to 5.5 percent by late 1971 .

\section{Procedure}

To provide a basis for a systematic evaluation of the St. Louis model, three sets of simulations were prepared. One simulation was based on coefficients estimated with data for the variables of the model through second quarter 1971, and used observed values for money and Federal expenditures to drive the model in the simulation period. This simulation is referred to as the "ex post" simulation. Another simu" lation, called "ex ante A," used coefficients estimated from data through fourth quarter 1969, and like the "ex post" simulation, actual data on money and Federal expenditures were used to drive the model. Finally, a simulation referred to as "ex ante $B$ " was run which again had coefficients based on data through late 1969, but steady growth rates of money and Federal expenditures (at their average rates over the simulation period from late 1969 to mid-1971) were used.

These three simulations were designed to identify the sources of error underlying model projections based on constant growth rates of money and Federal expenditures during the six-quarter period. ${ }^{5}$ Total error is defined as the difference between the observed value (either its level or rate of change) of a variable and the value projected in the ex ante $B$ simulation. These values for the variables in the ex ante $B$ simulation can be compared with those published in the April 1970 issue of this Review.

For purposes of evaluation, total projection error is divided into explained and unexplained error. Unexplained error is the difference between actual values and those yielded by the ex post simulation. Explained error is attributed to two factors - changing economic structure, which is reflected in changes in the coefficients, and deviations of monetary and fiscal variables from the assumed steady rates.

The method used here to identify the sources of error is summarized as follows:
Error

Actual minus Ex Post

Ex Post minus Ex Ante A

Ex Ante A minus Ex Ante B

Actual minus Ex Ante B
Defined as:

Unexplained

Due to changing economic structure

Due to steady rate assumption

Total error

\footnotetext{
The sources of error relate to the use and interpretation of the St, Louis model, and are not to be confused with studies of sources of forecasting error published by other investigators. See, for example, Jared J. Enzler and H. $O$. Stekler, "An Analysis of the 1968-69 Economic Forecasts," The Journal of Business (July 1971), pp. 271-81, for a discussion of forecast error attributable to inaceurate predictions of public policy.
} 
Unexplained error provides an indication of the overall reliability of the specification of the model. Error attributable to changing economic structure provides a measure of the stability of the coefficients over time, although with the addition of only six quarters of data, this is a very weak test of parameter stability. Finally, error attributable to the steady rate assumption regarding the monetary and fiscal variables sheds light on the usefulness of the model as a guide to the formulation of policy.

\section{Results}

The results of the three types of simulations with the St. Louis model for first quarter 1970 through second quarter 1971 are summarized in Table II and Chart II. The sources of error as defined above are shown in Table I. The focus of discussion is the average error for each variable, i.e., the last column of Table I. Rates of change in total spending, real product and prices are emphasized because the part of the model relating to these variables is estimated in first difference form, reflecting greater confidence in the statistical reliability of first difference estimates in the GNP accounts than of levels.

Total spending - Assuming steady growth of money and expenditures at the average rate that actually occurred (ex ante $B$ simulation), the average annual rate of change of total spending would have been overpredicted by 1.37 percentage points. Of this overprediction, 0,32 is unexplained. In other words, using all avalable information, including observations in the simulation period, but retaining the fundamental

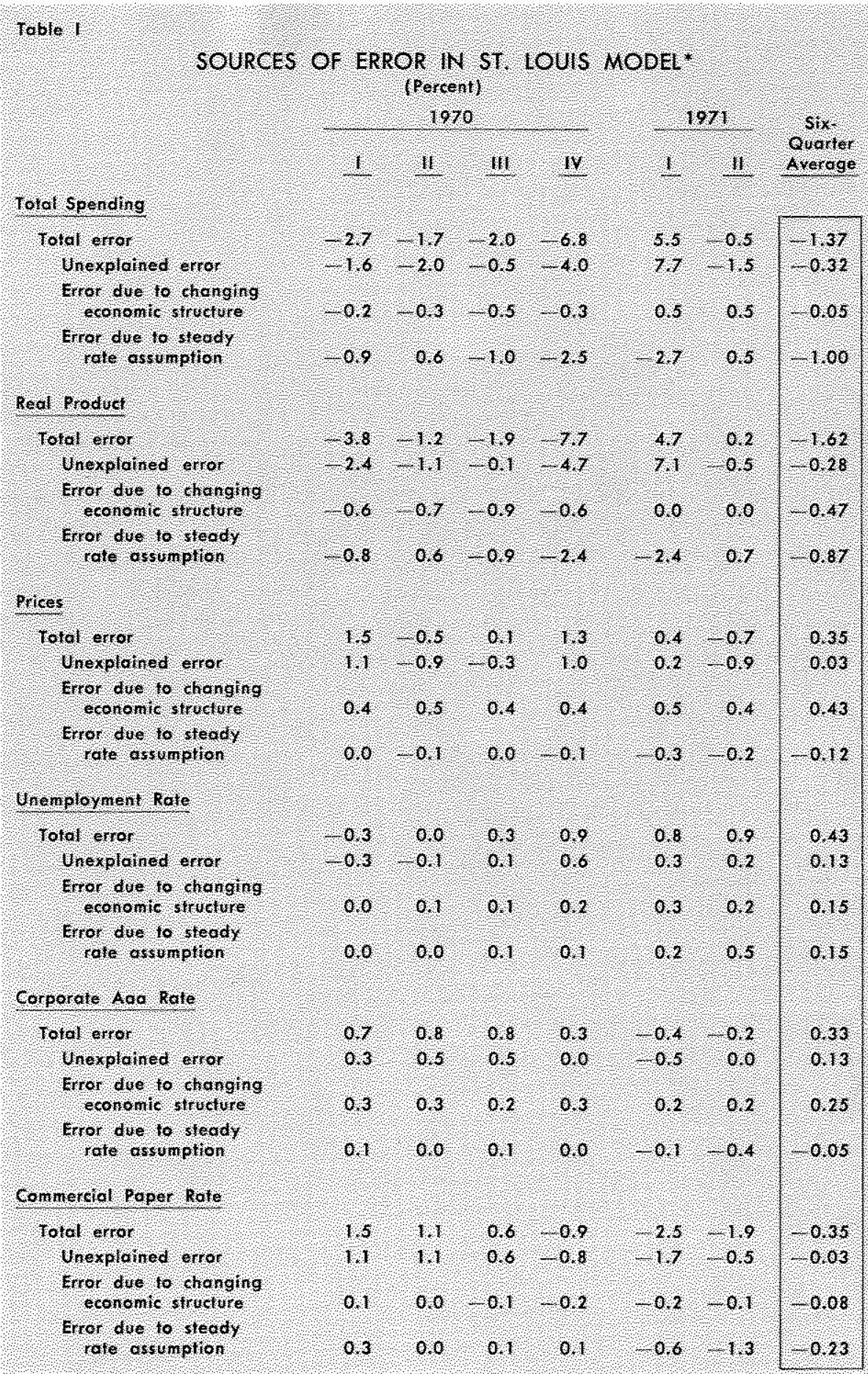

Totat en $0 \mathrm{r}=\mathrm{achal}, \mathrm{ex}$ antel

Une planed error $=$ newal es port

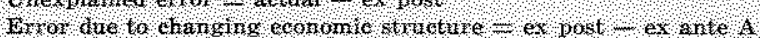

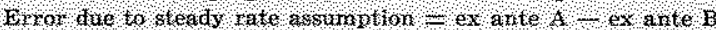

specification of the St. Louis model, average projection error was 0.32 percentage points for this period.

The average error associated with changing economic structure is .05 percentage points. Updating 


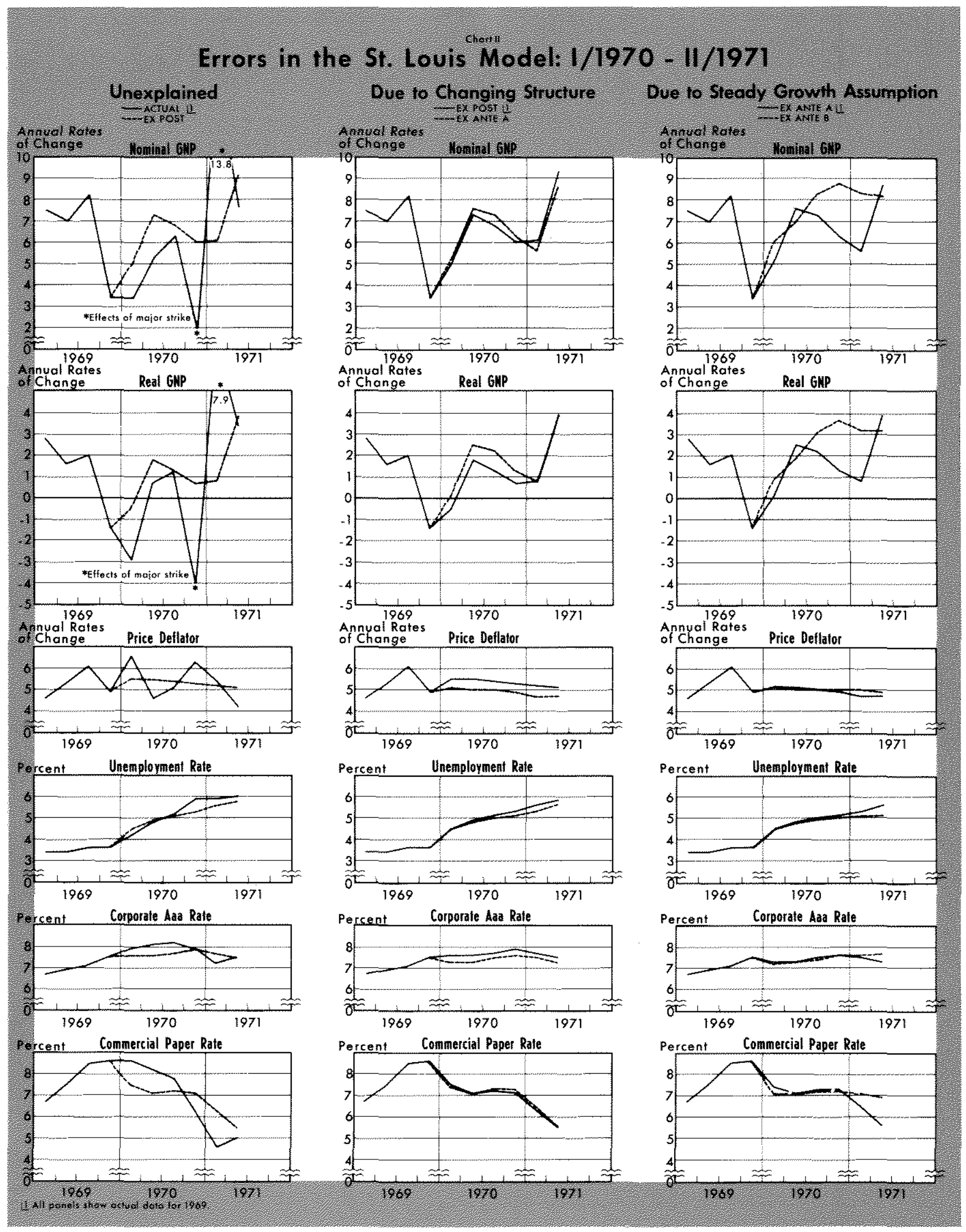


the coefficients with six additional quarters of data improves the accuracy of the total spending projection by .05 percentage points, on average.

The average error for total spending attributable to the assumption of steady growth of the policy variables is the largest, amounting to one percentage point. This result follows from the pattem of variability of quarter-to-quarter rates of change of both money and expenditures during this six-quarter period (see Chart 1). The annual rate of change of money varied from 4.2 to 11.3 percent to yield the 6.5 percent average rate of change for the period, whereas Federal expenditures varied between -3.4 and 24 percent, averaging 8.6 .

Error attributable to the steady rate assumption would not normally be expected to be this large, but it is a factor to consider when using this equation for a horizon as short as six quarters. It is not only the variability but also the pattern of the variability that leads to this type of error, For example, consider the accompanying figure on the following page, where two patterns of money growth are shown, both of which yield the same average for the period.

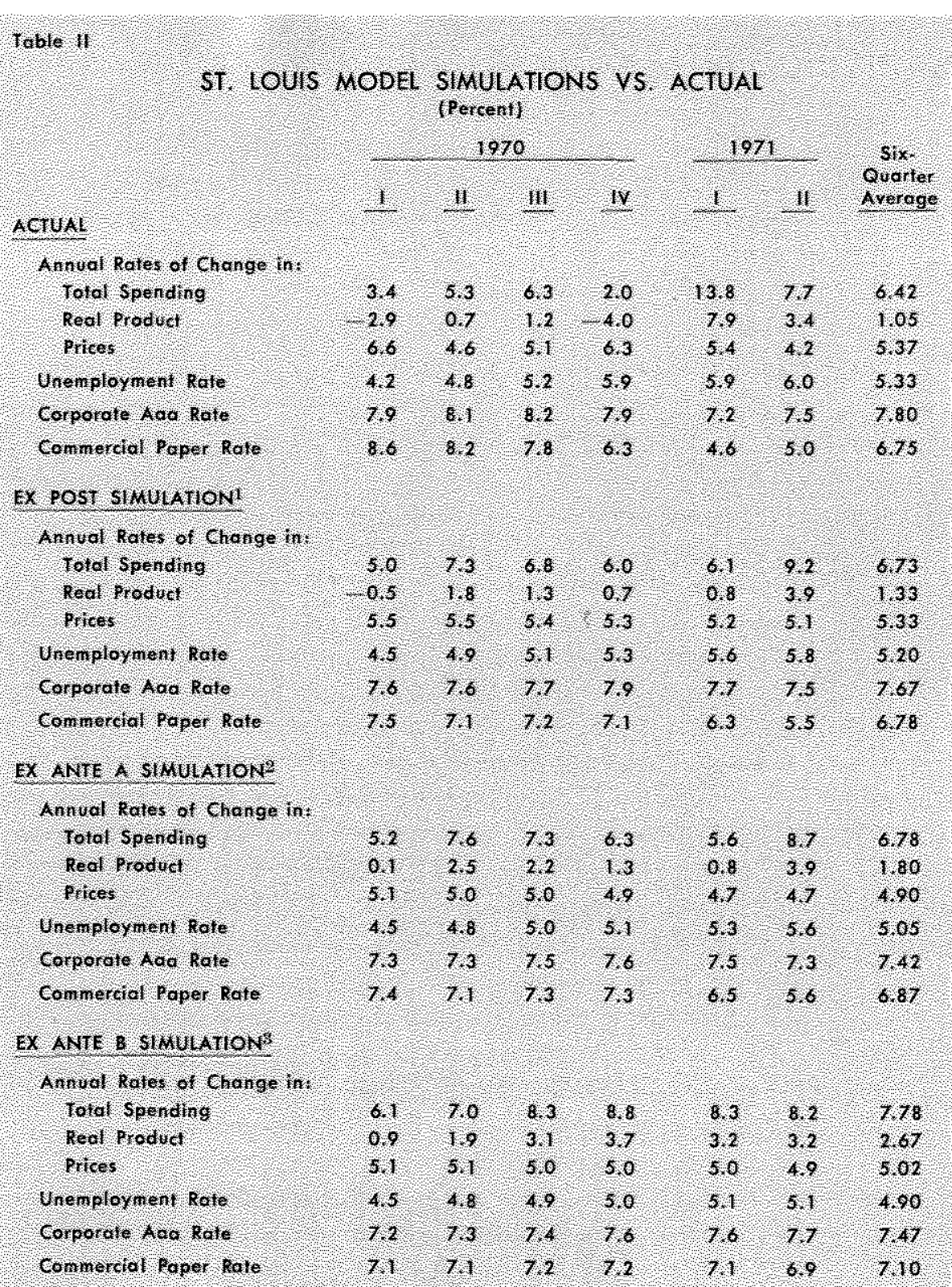

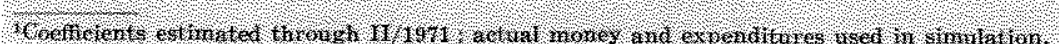

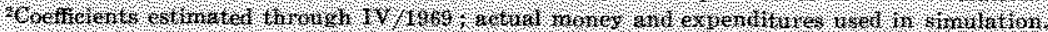

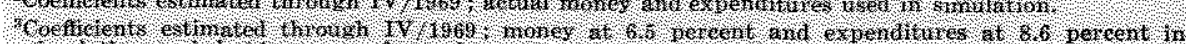

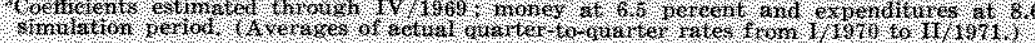

Because of the lags in the impact of monetary actions, the money growth pattem in Case $B$ will be associated with a larger growth of total spending for the period than in Case $\mathrm{A}^{6}$ If total spending growth were considered for a longer period of time, the pattern would be irrelevant. Furthermore, the error in total spending attributable to the steady rate assumption can be traced primarily to the pattern of variation in monetary growth, rather than Federal expenditures, because of the nature of the coefficients in the total spending equation. 6oney growth it 1971 is a case in point. Assuming lags in the impact of nonetary actions, as used in the St. Louis model, the steady rate equivalent is calculated as follows:

\begin{tabular}{rccc} 
& $\begin{array}{c}\text { Annual Rate of } \\
\text { Change of Money }\end{array}$ & Weight & $\begin{array}{c}\text { Weighted } \\
\text { Annual Rate } \\
\text { of Change }\end{array}$ \\
\cline { 2 - 3 }$I / 71$ & 7.3 & .375 & 2.74 \\
$I I / 71$ & 11.3 & .320 & 3.62 \\
$\mathrm{III} / 71$ & 7.7 & .214 & 1.65 \\
$\mathrm{IV} / 71$ & .4 & .090 & .04 \\
& & & 8.05
\end{tabular}

An unweighted average of the monetary growth rates would be 6.7 percent. The economic inpact of monetary actions in 1971 , thongh averaging a 6.7 percent growth, is the equim valent of an 8 percent steady rate in the 5 . Louis model. 




Prices - The total error for price projections was 0.35 percentage points during the six-quarter simulation period. However, unexplained error was negligible.

The major source of error in the price projections was associated with changing economic structure. Updating the price equation with observations from the six-quarter simulation period alters the coefficients significantly - in particular, increasing the coefficient on the weighted sum of past prices. The implications of this result are unclear, since our knowledge of the determinants of price level movements and price expectations and their interaction is so limited.

Error attributable to the steady rate assumption was in a direction opposite that due to changing economic structure. In other words, the steady growth case (ex ante $B$ ) tended to predict faster inflation than when the actual course of the policy variables (ex ante $A$ ) was included in the ex ante simulations. Like total spending, the error for prices attributable to the steady rate assumption can be traced to the pattern of variation in monetary growth.

Real product - The projections of real product are dependent on those for total spending and prices because real product is calculated by subtracting from the change in total spending that portion which is associated with estimated price change. Overprediction of total spending along with underprediction of prices leads to an average overprediction of real product of 1.62 percentage points. Unexplained error is about the same as for total spending because such error is negligible for prices.

Changing economic structure accounts for a substantial portion of total error for real product, reflecting the underprediction of prices. Error due to the steady rate assumption is also significant and of the same order of magnitude as for the total spending projections, though it does receive some correction from such error in the price projections. The real product projections bear the brunt of two types of errors - that due to the steady rate assumption in the total spending projections and that due to changing economic structure in the price projections.

Unemployment rate - Projections of the unemploy. ment rate can be expected to reflect the projection errors for real product. The total error associated with the unemployment rate averaged 0.43 percentage points. The total was equally divided among the three categories of error.

It should be noted that the sources of error are difficult to identify for the unemployment rate because the errors are derived from full model simulations rather than the unemployment equation alone. All types of error come into play, operating through total spending and prices, as well as the unemployment rate equation itself.

Corporate Aaa rate - Examination of the corporate Aaa rate projections indicate total error averaged 33 basis points. Unexplained error averaged 13 basis points, but changing economic structure is the key factor in the Aaa projections. This result is to be expected because price movements play an important role in the corporate Aaa equation. Because prices tended to be underpredicted in the ex ante A simulation, the Aaa rate is underpredicted also. There is a partial offset from the overprediction of real product growth, but clearly the price effect dominates.

Commercial paper rate-Commercial paper rate projections exhibit an average total error of about the same absolute magnitude as the corporate Aaa projection, but, in contrast, it is overpredicted. Surprisingly, both unexplained error and that due to changing economic structure are small during the simulation period. The reason is that the overprediction of real product and the underprediction of prices tended to offset each other. The price effect does not dominate the short-rate projections like it does the long-term rate.

Error attributable to the steady rate assumption accounts for most of the total error in the commercial paper rate projections. One of the reasons is that the direct effect of money tends to be larger in the short-rate equation than for the long rate. In addition, over-predictions of both real product and prices, as associated with the steady rate assumption effect, reinforce each other in the commercial paper rate projections.

\section{Conctusions}

The St. Louis model was not designed for quarterto-quarter forecasting. When interpreted in light of 
its objectives, the model succeeded in roughing out the average time paths of total spending, real product, prices, unemployment, and interest rates during the period from late 1969 to mid-1971. However, the degree of success can be gauged only by comparing the results with those of other models. ${ }^{7}$

${ }^{7}$ Some general comparisons with the Wharton model and the FRB-MIT-Penn model are given in Lawrence $R$. Klein, "Empirical Evidence on Fiscal and Monetary Models," in James J. Diamond, ed., Lsstes in Fiscal and Monetary Policy:
Policymakers and private forecasters may find that the St. Louis model is inadequate for many of their purposes-for example, quarter by quarter forecasts or detailed forecasts of the components of GNP. Nevertheless, it is hoped that this identification of strengths and weaknesses of the model will provide further understanding on its use and interpretation.

The Eclectric Economist Views the Controversy (DePaul University, 1971), pp. 35-50.

\section{APPENDIX}

\section{Estimated Equations of the St. Louis Model ${ }^{*}$}

\section{Total Spending Equation}

A. Sample period: I/1953 - IV/1969

$$
\begin{aligned}
\Delta \mathrm{Y}_{\mathrm{t}}=2.78+5.10 \Delta \mathrm{M}_{\mathrm{t}-1}+.10 \Delta \mathrm{E}_{\mathrm{t}-1} & \\
\text { (3.61)(7.99) } & \\
& \mathrm{R}^{2}=.66 \\
\text { S.E. } & =3.84 \\
\mathrm{D} \cdot \mathrm{W} & =1.80
\end{aligned}
$$

B. Sample period: I/1953- II/1971

$$
\begin{aligned}
\Delta \mathrm{Y}_{\mathrm{t}}=2.70+5.11 \Delta \mathrm{M}_{\mathrm{t}-\mathrm{i}}+.09 \Delta \mathrm{E}_{\mathrm{t}-\mathrm{i}} & \\
(.25)(7.37) \quad \mathrm{R}^{2} & =.58 \\
\mathrm{S.E} . & =4.53 \\
\mathrm{D}-\mathrm{W} & =2.1 .2
\end{aligned}
$$

\section{Price Equation}

A. Sample period: $\mathrm{I} / 1955-\mathrm{IV} / 1969$

$$
\begin{aligned}
& \Delta \mathrm{P}_{\mathrm{t}}=2.46+.09 \mathrm{D}_{\mathrm{t}-\mathrm{i}}+.93 \Delta \mathrm{P}_{\mathrm{t}}^{\mathrm{A}} \\
&(6.20)(8.64) \\
& \mathrm{R}^{2}=.87 \\
& \mathrm{S.E}=1.11 \\
& \mathrm{D}-\mathrm{W}=1.39
\end{aligned}
$$

B. Sample period: I/1955-II/1971

$$
\begin{aligned}
& \Delta P_{t}=2.05+.08 D_{t-i}+1.01 \Delta P_{t}^{A} \\
&(6.32)(8.38) \\
& R^{2}=.90 \\
& \text { S.E. }=1.23 \\
& \text { D-W }=1.67
\end{aligned}
$$

* Constraints and lag structures correspond to those sef forth in the original article discussing the St. Lowis model. See Ander. sen and Carlson, "A Monetarist Model." Coefficient values on lagged variables (subscripted " $t-1$ ") are sums of the coefficients for current and lagged quarters. Figures enclosed by parentheses under the coeficients are " $t$ " statistics.

\section{Unemployment Rate Equation}

A. Sample period: I/1955-IV/1969

$$
\mathrm{U}_{\mathrm{t}}=3.89+.04 \mathrm{G}_{\mathrm{t}}+.29 \mathrm{G}_{\mathrm{t}-1}
$$$$
\begin{array}{lll}
(70.59) & (.87) \quad(6.94)
\end{array}
$$

$\mathbf{R}^{2}=.92$

S.E. $=.31$

$\mathrm{D}-\mathrm{W}=.59$

B. Sample period: 1/1955 - II/1971

$$
\mathrm{U}_{\mathrm{t}}=3.88+.03 \mathrm{G}_{\mathrm{t}}+.29 \mathrm{G}_{\mathrm{t}-1}
$$$$
(72.41) \quad(.83) \quad(7.66)
$$

$$
\begin{aligned}
& \mathrm{R}^{2}=.92 \\
& \text { S.E. }=.30 \\
& \mathrm{D}-\mathrm{W}=.65
\end{aligned}
$$

\section{Long-Term Interest Rate Equation}

A. Sample period: I/1955-IV/1969

$$
\begin{aligned}
& \mathrm{R}_{\mathrm{t}}^{\mathrm{L}}=1.23-.06 \dot{\mathrm{M}}_{\mathrm{t}}+1.44 \mathrm{Z}_{\mathrm{t}}+.21 \dot{\mathrm{X}}_{\mathrm{t}-\mathrm{i}} \\
& (4.90)(-3.52) \quad(11.36) \quad(2.96) \\
& +.99 \dot{\mathrm{P}} /(\mathrm{U} / 4)_{\mathrm{t}-\mathrm{i}} \\
& \text { (18.51) }
\end{aligned}
$$

B. Sample period: I/1955- II/1971

$$
\begin{array}{ll}
\mathrm{R}_{\mathrm{t}}^{\mathrm{L}}=\underset{(4.77)(-3.56)}{1.29}-.06 \dot{\mathrm{M}}_{\mathrm{t}}+1.58 \mathrm{z}_{\mathrm{t}}+.15 \dot{\mathrm{X}}_{\mathrm{t}-\mathrm{1}} \\
+1.03 \dot{\mathrm{P}} /(\mathrm{U} / 4)_{1-\mathrm{i}} & \\
(19.96) & \\
& \mathrm{R}^{2}=.95 \\
& \mathrm{~S} . \mathrm{E} . \mathrm{D}=.31 \\
\mathrm{D}-\mathrm{W}=.79
\end{array}
$$




\section{Short-Term Interest Rate Equation}

A. Sample period: I/1955-IV/1969

$$
\begin{aligned}
& \mathrm{R}_{t}^{\mathrm{s}}=-1.07-.17 \dot{\mathrm{M}}_{t}+1.01 \mathrm{Z}_{+}+.66 \dot{\mathrm{X}}_{\mathrm{t}-\mathrm{i}} \\
& (-2.72)(-5.67) \\
& \text { (5.17) } \\
& +1.30 \dot{\mathrm{P}} /(\mathrm{U} / 4)_{\mathrm{t}-\mathrm{i}} \\
& \text { (15.17) } \\
& \mathrm{R}^{2}=.88 \\
& \text { S.E. }=.51 \\
& \mathrm{D}-\mathrm{W}=.54
\end{aligned}
$$

B. Sample period: I/1955- II/197I

$$
\begin{aligned}
\mathrm{R}_{\mathrm{t}}^{\mathrm{s}}= & -1.00-.18 \dot{\mathrm{M}}_{\mathrm{t}}+1.05 \mathrm{Z}_{\mathrm{t}}+.64 \dot{\mathrm{X}}_{\mathrm{t}-\mathrm{i}} \\
& (-2.19)(-5.21) \\
& +1.30 \dot{\mathrm{P}} /(\mathrm{U} / 4)_{\mathrm{t}-\mathrm{i}}
\end{aligned}
$$$$
\text { (14.33) }
$$

Symbols are defined as:

$$
\begin{aligned}
& \mathrm{R}^{2}=.87 \\
& \text { S.E. }=.60 \\
& \mathrm{D}-\mathrm{W}=.61
\end{aligned}
$$

$\Delta \mathrm{Y}=$ dollar change in total spending (GNP in current prices)

$\Delta \mathbf{M}=$ dollar change in money stock

$\Delta \mathrm{E}=$ dollar change in high-employment Federal expenditures
$\Delta \mathrm{P}=$ dollar change in total spending (GNP in current prices) due to price change

$\mathrm{D}=\Delta \mathrm{Y}-\left(\mathrm{X}^{\mathrm{F}}-\mathrm{X}\right)$

$\mathrm{X}^{\mathrm{F}}=$ potential output

$\mathrm{X}=$ output (GNP in 1958 prices)

$\Delta \mathrm{P}^{\mathrm{A}}=$ anticipated price change (scaled in dollar units)

$\mathrm{U}=$ unemployment as a percent of labor force

$\mathrm{G}=\left(\left(\mathrm{X}^{\mathrm{F}}-\mathrm{X}\right) / \mathrm{X}^{\mathrm{F}}\right) \cdot 100$

$\mathrm{R}^{\xi_{+}}=$Moody's seasoned corporate Aaa bond rate

$\dot{\mathrm{M}}=$ annual rate of change in money stock

$\mathrm{Z}=$ dummy variable $(0$ for $\mathrm{I} / 1955-\mathrm{IV} / 1960$ and 1 for $1 / 1961$ - end of regression period)

$\dot{\mathrm{X}}=$ annual rate of change in output (GNP in 1958 prices)

$\dot{\mathrm{P}} \quad=$ annual rate of change in GNP price deflator $(1958=100)$

$\mathrm{U} / 4=$ index of unemployment as a percent of labor force (base $=4.0$ )

$\mathrm{R}^{\mathrm{s}}=$ four- to six-month prime commercial paper rate

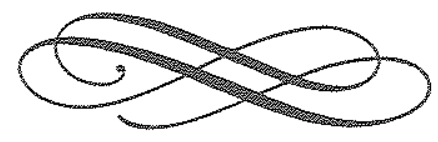

